\title{
HEAVY METAL BIOSORPTION BY CHITIN AND CHITOSAN ISOLATED FROM CUNNINGHAMELLA ELEGANS (IFM 46109)
}

\author{
Luciana de Oliveira Franco ${ }^{1,4}$; Rita de Cássia C. Maia ${ }^{2,4}$; Ana Lúcia F. Porto ${ }^{3}$; Arminda Sacconi Messias ${ }^{4}$; \\ Kazutaka Fukushima ${ }^{5}$; Galba Maria de Campos-Takaki**
}

\begin{abstract}
${ }^{1}$ Departamento de Bioquímica, Universidade Federal de Pernambuco, Recife, PE, Brasil; ${ }^{2}$ Departamento de Biologia de Fungos, Universidade Federal de Pernambuco, Recife, PE, Brasil; ${ }^{3}$ Departamento de Morfologia e Fisiologia Animal, Universidade Federal Rural de Pernambuco, Recife, PE, Brasil; ${ }^{4}$ Núcleo de Pesquisas em Ciências Ambientais, Departamento de Química, Universidade Católica de Pernambuco, Recife, PE, Brasil; ${ }^{5}$ Research Center for Pathogenic Fungi and Microbial Toxicoses, Chiba University, Chiba, Japan.
\end{abstract}

Submitted: April 27, 2004; Returned to authors for corrections: August 26, 2004; Approved: September 27, 2004

\begin{abstract}
Chitin and chitosan were extracted from mycelial biomass of Cunninghamella elegans and the performance for copper, lead and iron biosorption in aqueous solution was evaluated. The growth curve of $C$. elegans was accomplished by determination of biomass, $\mathrm{pH}$, glucose and nitrogen consumption. Chitin and chitosan were extracted by alkali-acid treatment and the yields were 23.8 and $7.8 \%$, respectively. For the adsorption analysis, the process of heavy uptake metal sorption was evaluated using polysaccharides solutions $(1 \% \mathrm{w} / \mathrm{v})$. The rate of metallic biosorption was dependent upon the concentration and $\mathrm{pH}$ of metal solutions, and the best results were observed with $\mathrm{pH}$ 4.0. Chitosan showed the highest affinity for copper and chitin for iron adsorption. The results suggest that $C$. elegans (IFM 46109) is an attractive source of production of chitin and chitosan, with a great potential of heavy metals bioremediation in polluted environments.
\end{abstract}

Key words: Cunninghamella elegans, chitin, chitosan, bioremediation, biosorption

\section{INTRODUCTION}

Heavy metals waste has increased rapidly since the industrial revolution. Toxic metal species are mobilized from industrial activities and fossil fuel consumption and eventually are accumulated through the food chain, leading to both ecological and health problems. Procedures for the removal of toxic metal species from contaminated environments have been developed and most of them are based on ion-exchange technologies and/ or precipitation of the cation in an inert form. Unfortunately, these methods are expensive and require the use of contaminating products for desorption of metals for cleaning up of the inorganic matrix $(6,7,8)$.

Recent researches in the field of heavy metals removal from wastewaters and sediments have focused on the development of materials with increased affinity, capacity and selectivity for target metals $(9,16)$. The use of microbial cells as biosorbents for heavy metals offers a potentially inexpensive alternative compared to conventional methods of heavy metal decontamination from a variety of industrial aqueous process streams $(7,10,11)$.

The recent interests on the metal uptake by microorganisms have improved new technologies for metal removal or recovery of wastewater. Many micro fungi contain chitin and chitosan as an integral part of their cell wall structure, and the binding of toxic products and heavy metal ions by these polysaccharides is a direct consequence of the base strength of the amine group $(3,6,15)$.

Chitin and its deacetylated derivative, chitosan, have unique properties, which make them useful for a variety of applications. The traditional source of chitin is shellfish waste from shrimp,

*Corresponding author. Mailling address: Núcleo de Pesquisas em Ciências Ambientais, Universidade Católica de Pernambuco, Rua Nunes Machado, 42 Bloco J. 50050-590, Recife, PE, Brasil. Tel.: (+5581) 3216-4017. Fax: (+5581) 3216-4017. E-mail: galba_takaki@yahoo.com.br 
Antarctic Krill, crab and lobster processing $(12,17)$. However, the industrial isolation of this polymer is reduced by the problems of seasonal and limited supply in some countries and environmental pollution while collecting large amounts of shell waste $(18,20)$.

In this work, we report the microbial production of chitin and chitosan extracted from mycelia of Cunninghamella elegans (IFM 46109) and the application for recovery heavy metals in aqueous solutions.

\section{MATERIALS AND METHODS}

\section{Microbiological Methods}

Growth profile: the spores of $C$. elegans were harvested from cultures grown for seven days at $28^{\circ} \mathrm{C}$ on Petri dishes containing PDA medium. A suspension was prepared and adjusted to $10^{7}$ spores $/ \mathrm{mL}$, using an haemocytometer for counting. Fifty $\mathrm{mL}$ of synthetic medium for Mucorales (1) $(60 \mathrm{~g}$ glucose; $3 \mathrm{~g}$ asparagine; $0.08 \mathrm{mg}$ chloridrate of thiamine; $0.50 \mathrm{~g}$ potassium phosphate and $0.25 \mathrm{~g}$ magnesium sulphate per liter of distilled water, $\mathrm{pH}$ 5.1) was distributed in Erlenmeyer flasks $(250 \mathrm{~mL})$ and incubated at $28^{\circ} \mathrm{C}$ in an orbital shaker at $150 \mathrm{rpm}$ during 96 hours. At every 12 hours, aliquots were collected for biomass, $\mathrm{pH}$, glucose and total nitrogen determinations. The mycelia were harvested and washed twice in destilled and deionoized water by filtration utilizing a silkscreen nylon membrane $(120 \mathrm{~F})$. For biomass production determination, the cell suspension was submitted to liophylization and mantained in a vacuum dissecator until constant weight.

\section{Analytical Methods}

Glucose, nitrogen and $\mathbf{p H}$ determinations: The glucose consumption was determined by the enzymatic colorimetric method (Labtest ${ }^{\circledR}$ Kit - Glucose oxidase). A standard curve was elaborated by using a glucose solution ( 0.5 to $10.0 \mathrm{~g} / \mathrm{L})$. Colorimetric method Labtest ${ }^{\circledR}$ Kit for protein was utilized for the nitrogen consumption determination, using a spectrophotometer Spectronic Genesys 2. Changes in $\mathrm{pH}$ were measured by potenciometry. All assays were performed two times.

Extraction of chitin and chitosan : the process of extraction involved deproteinization with $2 \% \mathrm{w} / \mathrm{v}$ sodium hydroxide solution $\left(30: 1 \mathrm{v} / \mathrm{w}, 90^{\circ} \mathrm{C}, 2 \mathrm{~h}\right)$, separation of alkali-insoluble fraction (AIF) by centrifugation ( $4000 \mathrm{rpm}, 15 \mathrm{~min}$.), extraction of chitosan from AIF under reflux (10\% v/v acetic acid 40:1 v/w, $60^{\circ} \mathrm{C}, 6 \mathrm{~h}$ ), separation of crude chitin by centrifugation $(4000 \mathrm{xg}$, $15 \mathrm{~min}$.) and precipitation of chitosan from the extract at $\mathrm{pH} 9.0$, adjusted with a $4 \mathrm{M} \mathrm{NaOH}$ solution. Crude chitin and chitosan were washed on a coarse sintered-glass funnel with distilled water, ethanol and acetone and air-dried at $20^{\circ} \mathrm{C}(20)$.

Chitin and chitosan characterization: The polysaccharides resulting from the mycelia of $C$. elegans as well as the commercial polysaccharides Sigma ${ }^{\circledR}$ utilized as standard were characterized by FT-IR Spectra spectral analyses (Kbr discs; Bruker 66 Spectrometer). The degree of deacetylation (D.D.) for microbial chitosan was determined using titration method accordind to Toei and Kohara (24). $0.5 \mathrm{~g}$ of chitosan was dissolved in $99.5 \mathrm{~g}$ $5 \%$ formic acid $(\mathrm{v} / \mathrm{v}) .1 \mathrm{~g}$ of biomaterial/formic acid solution was mixed with distilled water $(30 \mathrm{~mL})$. After adding 2 to 3 drops of $0.1 \%$ toluidine blue (indicator), the solution was titrated with $\mathrm{n} /$ 400 PVSK (potassium polyvinilsulphate) calibrated with cetylpyridinium chloride monohydrate. The D.D. was calculated as follows: D.D. $=[\mathrm{X} / 161 /(\mathrm{x} / 161+\mathrm{Y} / 203)] \mathrm{x} 100(\mathrm{X}=1 / 400 \times 1 /$ $1000 \times f \times 161 \times \mathrm{V}$; where: $\mathrm{Y}=0.5 \times 1 / 100-\mathrm{X} ; \mathrm{V}=$ titred volume $(\mathrm{mL})$ of $\mathrm{n} / 400$ PVSK and $f=$ factor of $\mathrm{n} / 400$ PSVK solution (24).

Metal Uptake Determination: solutions of iron $\left(\mathrm{Fe}^{+2}\right)$, lead $\left(\mathrm{Pb}^{+2}\right)$ and copper $\left(\mathrm{Cu}^{+2}\right)$ at $1,2,3$ and $4 \mathrm{mM}$ of concentration were prepared, and the $\mathrm{pH}(3,4$ and 5$)$ was adjusted using $1 \mathrm{~N}$ sodium hydroxide or $10 \%$ acetic acid. The polysaccharides chitin or chitosan $(1 \% \mathrm{w} / \mathrm{v})$ were added into the flasks and submitted to orbital shaker at $200 \mathrm{rpm}$ at $25^{\circ} \mathrm{C}$ for $18 \mathrm{~h}$. The polysaccharides were removed by filtration through a $0.45 \mathrm{~mm}$ Millipore membrane filter, and the metal concentrations in filtrates were determined using an atomic absorption spectrophotometer. All experiments were performed three times. The data were used to calculate the number of moles of metal ion adsorbed per gram of biomaterials. The metal recovery was calculated according to the equation: $\mathrm{q}=\mathrm{C}_{\mathrm{i}}-\mathrm{C}_{\mathrm{f}} / \mathrm{m}$, where: $\mathrm{q}=$ metal uptake; $\mathrm{C}_{\mathrm{i}}=$ initial concentration; $\mathrm{C}_{\mathrm{f}}=$ final concentration and $\mathrm{m}=$ polysaccharide concentration (25).

\section{RESULTS}

The growth profile of $C$. elegans during $96 \mathrm{~h}$ showed a well defined adaptation phase until eight hours of incubation. Biomass production increased rapidly up to $48 \mathrm{~h}$. The culture reached $11.0 \mathrm{~g}$ of dried mycelia per litter of medium at 96 hours. The $\mathrm{pH}$ of the media dropped gradually during fungal growth. For the period of the fungal growth, the protein contents in the metabolic liquid decreased steadily to almost imperceptible quantities, while the glucose consumption was not total by the end of cultivation (Fig. 1).

The chitin and chitosan yields in the lyophilized mycelia after $96 \mathrm{~h}$ of cultivation were $23.8 \%$ and $7.8 \%$, respectively. The deacetylation degree for chitosan isolated from C. elegans was 72.3. The profiles of infrared spectrum of the polysaccharides extracted from the cells were almost similar to those present in commercial chitin and chitosan $\left(\right.$ Sigma $\left.^{\circledR}\right)$, utilized as standards. Chitosan showed the most significant peaks at 1284, 1386 and $1513 \mathrm{~cm}^{-1}$, which correspond to the amide bonds. For chitin the most significant parts of the spectra showed the amide bonds at approximately 1158,1378 and $1558 \mathrm{~cm}^{-1}$ (Fig. 2).

The metal recovery of $\mathrm{Fe}^{2+}, \mathrm{Pb}^{2+}$ and $\mathrm{Cu}^{2+}$ in aqueous solution by chitin and chitosan produced from C. elegans 


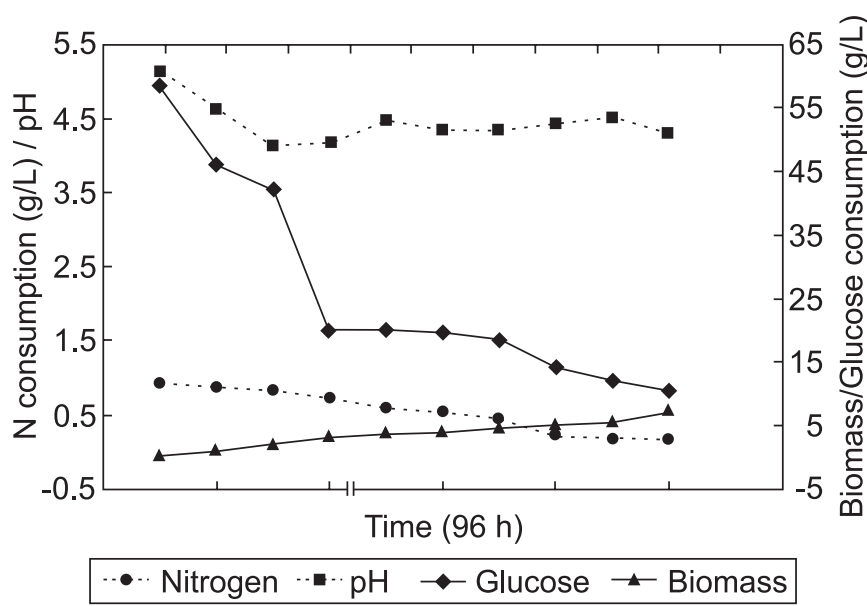

Figure 1. Growth profile of C. elegans (IFM 46109) in synthetic medium for Mucorales. was investigated. The metal concentration in aqueous solutions (varing from 1 to $4 \mathrm{mM}$ ) and the influence of the $\mathrm{pH}$ (3, 4 and 5) were also investigated in order to determine the effect of these parameters on the removal of metal ions by polysaccharides. Table 1 shows the average of results obtained from three replicates. Uptake data for each metal ion agreed with the final metal concentration in the aqueous solution. Control experiments without the biopolymers were carried out for each metal ion and the filter membrane was analyzed to demonstrate that it did not absorb them. Metallic removal was extremely dependent on $\mathrm{pH}$, metal utilized and concentration of solutions. For almost all metals the best results were observed at $\mathrm{pH}$ 4.0. The metal recovery values for chitin and chitosan, as well as the influence of the metal concentration and $\mathrm{pH}$, are show in Table 1. Chitosan was the polysaccharide with best capacity for copper biosorption (75\%). Chitin presented the maximum iron uptake (56\%), both at $\mathrm{pH} 4$ and up to $2.0 \mathrm{mM}$ heavy metal concentration.
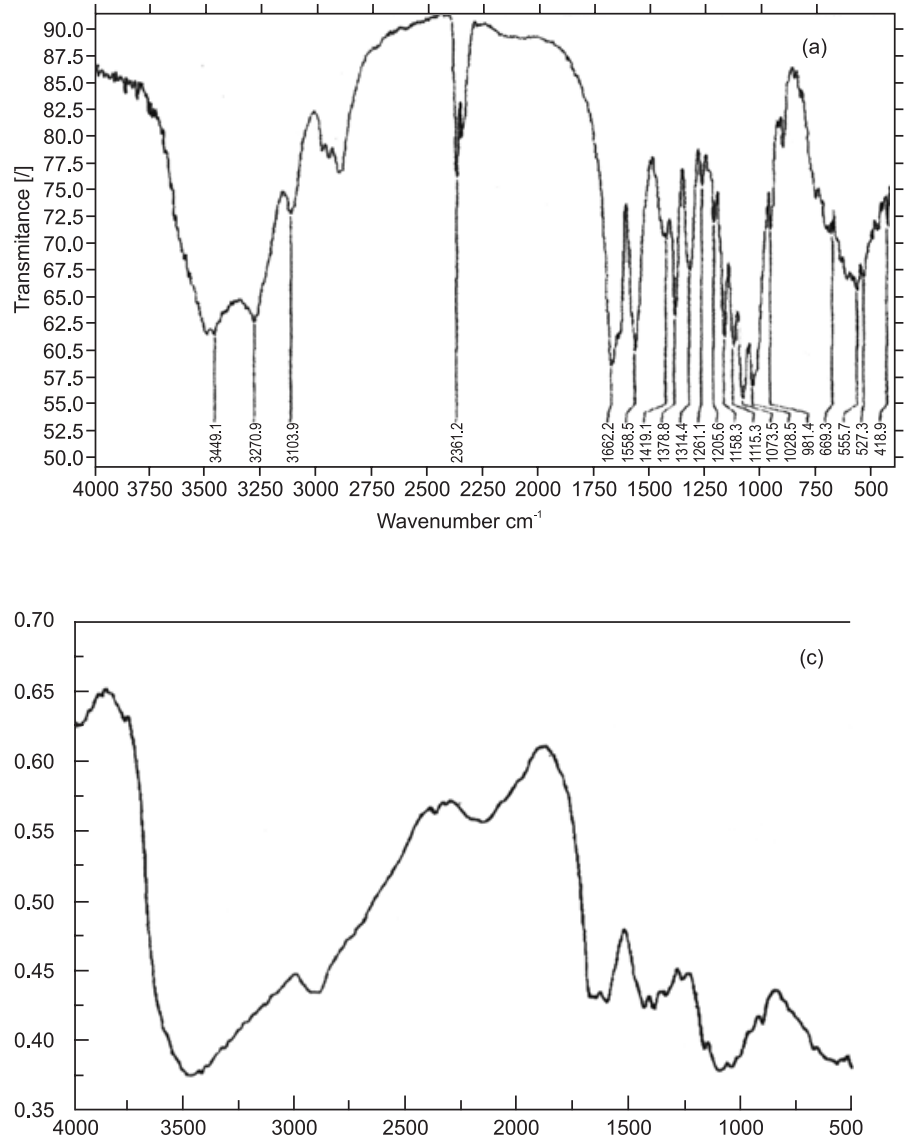
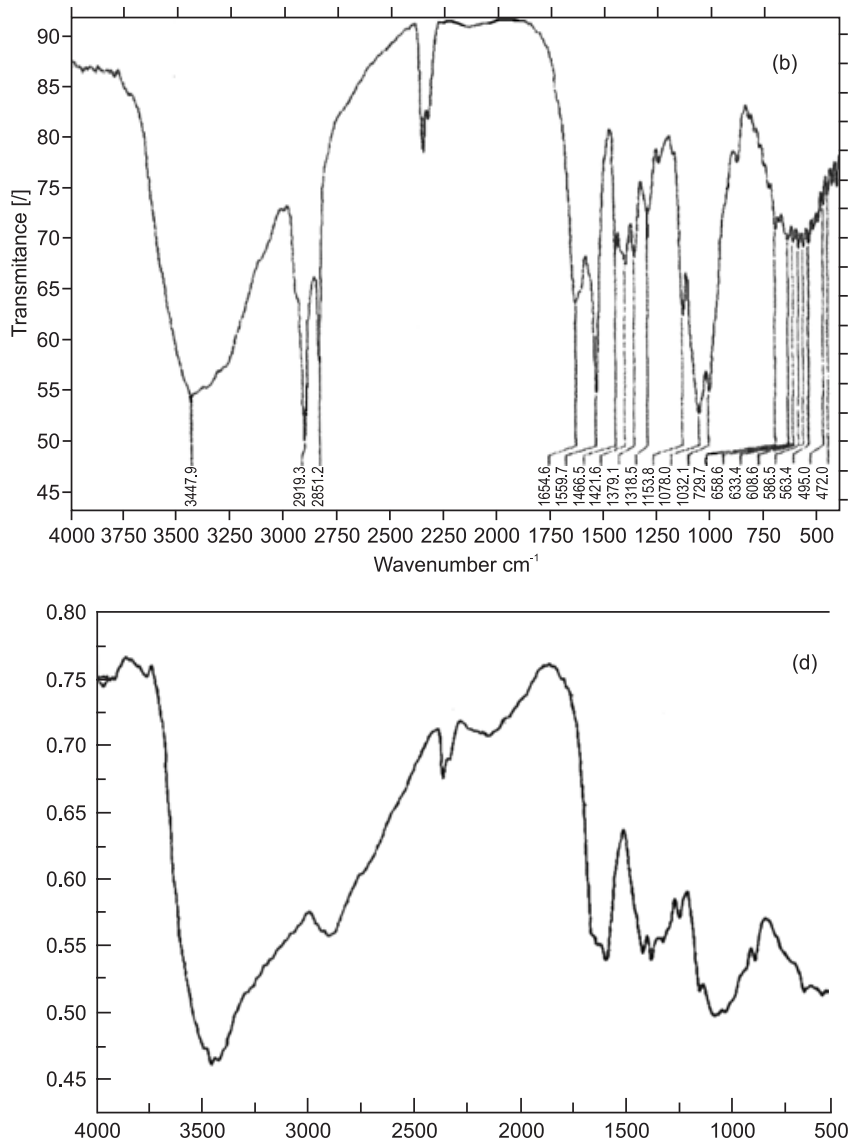

Figure 2. Infra-red spectrum of polysaccharides. (a) Chitin standard, (b) Fungi chitin, (c) Chitosan standard and (d) Fungi chitosan. 
Table1. Heavy metal recovery by chitin and chitosan from $C$. elegans (IFM 46109).

\begin{tabular}{|c|c|c|c|c|c|c|c|}
\hline \multirow{2}{*}{\multicolumn{2}{|c|}{ Metal }} & \multicolumn{3}{|c|}{$\begin{array}{c}\text { Sorption by } \\
\text { chitin (\%) } \\
\text { pH }\end{array}$} & \multicolumn{3}{|c|}{$\begin{array}{c}\text { Sorption by } \\
\text { chitosan }(\%) \\
\text { pH }\end{array}$} \\
\hline & & 3 & 4 & 5 & 3 & 4 & 5 \\
\hline \multirow[t]{4}{*}{$\mathrm{Fe}^{2+}$} & 1 & 38.0 & 49.0 & 34.0 & 46.8 & 54.8 & 42.0 \\
\hline & 2 & 42.0 & 56.0 & 48.0 & 52.8 & 52.0 & 49.0 \\
\hline & 3 & 31.3 & 34.9 & 34.4 & 41.2 & 46.6 & 30.7 \\
\hline & 4 & 36.0 & 16.0 & 24.0 & 20.0 & 30.0 & 18.0 \\
\hline \multirow[t]{4}{*}{$\mathrm{Pb}^{2+}$} & 1 & 38.0 & 43.0 & 37.0 & 47.0 & 50.0 & 35.0 \\
\hline & 2 & 38.0 & 45.0 & 35.0 & 42.0 & 52.0 & 46.0 \\
\hline & 3 & 27.0 & 32.0 & 28.0 & 38.0 & 48.0 & 27.0 \\
\hline & 4 & 16.0 & 27.0 & 18.5 & 29.0 & 32.0 & $\mathbf{3 0 . 0}$ \\
\hline \multirow[t]{4}{*}{$\mathrm{Cu}^{2+}$} & 1 & 40.0 & 45.0 & 36.0 & 44.0 & 48.0 & 42.0 \\
\hline & 2 & 48.0 & 50.0 & 46.0 & 40.0 & 75.0 & 43.0 \\
\hline & 3 & 36.0 & 43.0 & 37.0 & 36.0 & 40.0 & 26.0 \\
\hline & 4 & 12.5 & 13.5 & 11.5 & 34.0 & 23.0 & 32.5 \\
\hline
\end{tabular}

\section{DISCUSSION}

The mycelia yield of $C$. elegans in the used medium, was good when compared to other microorganisms's biomass production. The maximum production was $11.6 \mathrm{~g}$ per liter, superior to the biomass of Mucor rouxii described by Synowieck and Al-Khateeb (20) who obtained $4 \mathrm{~g}$ of dry cell mass per liter of medium. Andrade et al. (1), working with $C$. elegans, obtained a biomass yield similar to ours $(10.4 \mathrm{~g} / \mathrm{L})$. The $\mathrm{pH}$ values during fungi growth were analogous to the results of Andrade et al. (1), Synowieck and Al-Khateeb (20), and White et al. (27). Glucose and protein consumption showed a classical performance of 96 hours of fungi growth.

Chitin and chitosan are found in all Zygomycetes $(2,12)$. Biopolymer production from C. elegans is generally equivalent to or higher than that from other microorganisms or from other traditional sources, like mollusk and crustacean carapaces $(1,4)$. The chitin and chitosan production from C. elegans was similar to those described by others authors: Elorza et al. (5) isolated chitin from Candida albicans and obtained 21.6\%. Synowiecki and Al-Katteb (20) proposed Mucor rouxii as a promising chitin and chitosan source, but reached a maximum yield of $8.9 \%$ for chitin and $7.3 \%$ for chitosan. Our results were better than those described by Chattaway et al. (3) and Sullivan et al. (19), who isolated chitin from C. albicans obtaining $10.0 \%$ and $2.7 \%$, respectivelly. Knorr (11) obtained 9\% of chitin in the mycelia fraction from $M$. rouxii. The infra-red spectra of chitin and chitosan from C. elegans were similar to those reported in the literature $(21,22)$ and also to the infra red spectra of these polysaccharides produced from shellfish by Sigma ${ }^{\circledR}$, which were used as standards. The degree of deacetylation (D.D.) influenced the physical and chemical properties of chitosan, as well as its biological activity. The D.D. value for chitosan (72.3\%) corresponded to the acetyl groups content of $9-22 \%$ determined in other microbial chitosans (21).

Microorganisms generally accumulate metals on the cell wall and in periplasmic space. Passive metal ion adsorption by the cell wall is frequently denoted as biosorption and does not depend on cellular metabolic activity. The predominance of negatively charged free groups in several biopolymers that form the cell wall confers an anionic character on the cell surface, resulting in passive attraction of various metal cations $(7,23)$. Thus the binding of metal ions to cell surface is assumed to be due to electrostatic interaction, leading, in some cases, to formation of complexes between metal cations and different functional binding groups found in carbohydrates, lipids, protein and others biopolymers of microbial cell envelop $(6,7)$.

The $\mathrm{pH}$ of the metal solutions affects the biosorption because it determines the availability of the metal in a soluble form for adsorption, and dictates the overall surface charge of the adsorbent (23). Ours results show clearly that the maximum adsorption of almost all metal ions studied occurred at $\mathrm{pH} 4$, showing that the removal process was highly dependent on the $\mathrm{pH}$ of the metal solutions, which affects the surface charge of the biosorbents and the degree of ionization $(6,24)$.

The metal adsorption by chitin and chitosan in aqueous solution was directly influenced by the metal concentration. Metal removal increased with the increase of metal concentration up to $2 \mathrm{mM}$ and then fell or remained constant. Galli et al. (6) and Ozer et al.(13) obtained similar results, and this phenomenon was described as "saturation type reaction rate".

The best results found for chitin were for iron recovery (56\%) and for chitosan, cooper recovery ( $75 \%$ ). These results are similar to those reported by Wales and Sagar (26), who obtained values of 18 to $76 \%$ for cooper recovery by mycelia of Zygomycetes. Tobin et al. (23), using Rhyzopus arrhizus biomass, obtained $54 \%$ of recovery for uranium. Parker et al., (14) evaluating cadmium and cooper sorption by Microcystis aeruginosa, showed values between 22 and $61 \%$ of metal recovery. Strandberg et al. (18) proposed dry mycelia of Saccharomyces cerevisae and Pseudomonas aeruginosa for $\mathrm{Pb}^{2+}$ recov7ery and showed results of about $30 \%$ and $50 \%$, respectively. These results are lower than those obtained for chitin and chitosan extracted from $C$. elegans (IFM 46109), suggesting that this microorganism has a biotechnological potential as source for polysaccharides production and metal bioremediation of contaminated water.

\section{ACKNOWLEDGEMENTS}

We are grateful to CNPq, CAPES, UNICAP, FINEP, and PRONEX for the financial support. 


\section{RESUMO}

\section{Remoção de metais pesados por quitina e quitosana isoladas de Cunninghamella elegans (IFM 46109)}

Quitina e quitosana foram extraídas a partir da massa micelial de Cunninghamella elegans (IFM 46109) e avaliou-se a aplicação destes polissacarídeos na remoção dos metais pesados cobre, chumbo e ferro preparados em solução aquosa. $\mathrm{O}$ crescimento de C. elegans foi acompanhado através da determinação de biomassa, $\mathrm{pH}$, consumo de glicose e de nitrogênio. A extração de quitina e quitosana realizou-se através de tratamento álcali-ácido e a produção dos polissacarídeos foi de 23,8 e 7,8 \%, respectivamente. A avaliação do processo de remoção dos metais pesados foi realizada utilizando-se os polissacarídeos em solução a $1 \%$ (p/v). Os níveis de biossorção de metais foram dependentes da concentração e do $\mathrm{pH}$ das soluções. Os melhores resultados foram obtidos em pH 4,0. A quitosana mostrou maior índice de biossorção para o íon cobre e a quitina para o ferro. Os resultados sugerem que C.elegans pode ser considerada uma fonte atrativa para a produção alternativa de quitina e quitosana, e que demonstra grande potencial de biossorção de metais pesados em ambientes poluídos.

Palavras-chave: Cunninghamella elegans, quitina, quitosana, biossorção, biorremediação

\section{REFERENCES}

1. Andrade, V.S.; Neto, B.B.; Souza, W.; Campos-Takaki. G.M. A factorial design analysis of chitin production by Cunninghamella elegans. Can. J. Microbiol., 46:1042-1045, 2000.

2. Arcidiacono, S.; Lombardii, S.J.; Kaplan, D.L. Fermentation processing and enzyme characterization for chitosan biosynthesis by Mucor rouxii. In: Anthonsen, T.; Sanford, P. Chitin and chitosan. Ed. G. Skjak-Braek.. Elsevier appl. Sci. London, New York, 1989, 319-332 pp.

3. Chattaway, F.W.; Holmes, M.R.; Barlow, A.J.E. Cell wall composition of the mycelial and blastospore forms of Candida albicans. J. Gen. Microbiol., 51:367-376, 1968

4. Chung, L.Y.; Shimidt, R.J.; Hamly, P.F.; Sagar, B.F.; Andrews, A.M.; Turner, T.D. Biocompatibility of potential wound management products: hydrogen peroxide generation. J. Biomed. Mat. Res., 39:300-307, 1994.

5. Elorza, M.V.; Sentandreu, R.; Ruiz-Herrera, J. Isolation and characterization of yeast monomorphic mutants of Candida albicans. J. Bacteriol., 176:2318-2325, 1994.

6. Galli, E.; Mario, F.Di.; Rapana, P.; Lorenzoni, P.; Angelini. Copper biosorption by Auricularia polytricha. Let. Appl. Microbiol., 37:133137, 2003.
7. Gomes, N.C.M.; Mendonça-Hagler, L.C.S.; Savaidis, I. Metal Biorremediation by Microorganisms. Rev. Microbiol., 29:85-92, 1998.

8. Hernadez, A.; Mellado, R.P.; Martinez, J.L.; Metal accumulation and vanadium-induced multidrug resistence by environmental isolates of Echerichia coli and Enterobacter cloacae. Appl. Environ. Microbiol., 1:4317-4320, 1998.

9. Jianlong, W.; Xinmin, Z.; Decai, D.; Ding, D. Bioadsorption of lead (II) from aqueous solution by fungal biomass of Aspergillus niger. $J$. Biotechnol., 87:273-277, 2001.

10. Khoo, K.M.; Ting, Y.P. Biosorption of gold by immobilized fungal biomass. Biochem. Engin. J., 8:51-59, 2001.

11. Knorr, D. Recovery and utilization of chitin and chitosan in food processing waste management. Food Technol., 45:114-122, 1991.

12. Muzzarelli, R. A. A. Chitin. Pergamon Press. New York, 1977, 97p.

13. Özer, A.; Özer, D.; Ekiz, H.I. Application of Freudlich and Langmuir models to multistage purification process to remove heavy metal ions using Schizomeris leibleinni. Proc. Biochem., 34:919-927, 1999.

14. Parker, D.L.; Rai, L.C.; Mallick, N.; Rai, P.K.; Kumar, H.D. Effects of cellular metabolism and viability on metal ion accumulation by cultured biomass from a blom of the Cyanobacterium Mycrocistis aeruginosa. Appl. Environ. Microbiol., 64:1545-1547, 1998.

15. Roberts, G.A.F. Chitin chemistry. Marcmillan Press. Ltd. London 1992, 251p

16. Schmuhl, R.; Krieg, H.M.; Keizer, K. Adsorption of $\mathrm{Cu}(\mathrm{II})$ and $\mathrm{Cr}(\mathrm{VI})$ ions by chitosan: kinetcs and equilibrium studies. Water SA, 27(1):18, 2001.

17. Shahidi, F.; Synowiecki, J. Isolation and characterization of nutrients and value-added products from snow crab (Chinoecetes apilio) and shrimp (Pandalus borealis) processing discards. J. Agric. Food Chem., 39:1527-1532, 1991.

18. Strandberg, G.W.; Shumate II, S.E.; Parrot Jr, J.R. Microbial cells as biosorbents for heavy metals: accumulation of Uranium by Saccharomyces cerevisae and Pseudomonas aeruginosa. Appl. Environ. Microbiol., 41:237-245, 1981.

19. Sullivan, P.A.; Yin, C.Y.; Molloy, C. Templeton, M.D., Shepherd, M.G. An analysis of the metabolism and cell wall composition of Candida albicans during germ tube formation. Can. J. Microbiol., 29:1514-1525, 1983

20. Synowiecki, J.; Al-Khatteb, N.A.AQ. Mycelia of M. rouxii as a source of chitin and chitosan. Food Chem., 60(4):605-610, 1997.

21. Synowiecki, J.; Al-Khatteb, N.A.AQ. Production, properties, and some new applications of chitin and derivates. Crit. Rev. Food. Sci. Nutr., 43(2):145-171, 2003.

22. Tharanathan, N.R.; Kitter, F.S. Chitin - The undisputed biomolecule of great potential. Crit. Rew. Food Sci.Nutr., 43(1):61-87, 2003.

23. Tobin, J.M.; White, C.; Gadd, G.M. Metal accumulation by fungi: applications in environmental biotechnology. J. Ind. Microbiol., 13:126-130; 1994.

24. Toei, K.; Kohara, T. Analyt. Chem., Acta. New York, 1976, 59p.

25. Volesky, B.; Holan, Z;R. Biosorption of heavy metals. Am. Chem. Soc. American Institute of Chemical Engineers. 1995, 235-251p.

26. Wales, D.S.; Sagar, B.F. Recovery of metal ions by microfungal filters. J. Chem. Tech. Biotechnol., 49:345-355, 1990.

27. White, S.A.; Farina, P.R.; Fulton, I. Production and isolation of chitosan from Mucor rouxii. Appl. Environ. Microbiol., 38:323$328,1979$. 